\title{
The Survival of Stationary Phase Aerobacter aerogenes Stored in Aqueous Suspension
}

\author{
By R. E. STRANGE, F. A. DARK ANd A. G. NESS \\ Microbiological Research Establishment, Porton, Wiltshire
}

(Received 13 October 1960)

\begin{abstract}
SUMMARY
The survival characteristics of washed stationary phase Aerobacter aerogenes organisms suspended in buffered sodium chloride solution and stored at room temperature, or at $37^{\circ}$ with aeration, depended on the medium used for growing the bacteria. Populations of bacteria harvested from tryptic meat broth or tryptone glucose medium remained almost completely viable for longer periods than bacteria from a simple ammonium salt + mannitol medium in which carbon was limiting. Analyses of washed freeze-dried preparations of freshly harvested bacteria showed that the amounts of protein, carbohydrate and ribonucleic acid present varied according to which of the above media was used for growth. During the initial stages of storage at $37^{\circ}$, when the viability of the population remained apparently unchanged, a progressive loss in bacterial dry weight occurred, due to degradation of these cell constituents. Endogenous glycogen was degraded and oxidized; bacteria which contained glycogen survived well. However, the addition of glucose to suspensions stored under aerobic or anaerobic conditions did not favour survival. Utilization of substances made available by degradation of various endogenous macromolecular constituents may be an important factor concerned with the survival of bacteria in unfavourable environments.
\end{abstract}

\section{INTRODUCTION}

Harrison (1960) showed that population density affected the survival of bacteria held under growth conditions in the absence of added nutrients. Products from dead or dying bacteria are utilized by the living organisms, allowing maintenance of viability or division to occur. It is possible that another important factor concerned with bacterial survival is the ability of a bacterium to maintain itself by utilizing some of its own internal constituents. The problem of energy reserve substances in bacteria was reviewed by Wilkinson (1959); he considered that these substances are probably homoglycans (glycogen), poly- $\beta$-hydroxybutyrate, other lipids (triglycerides) and polyphosphate. The accumulation and breakdown of internal glycogen was studied in Escherichia coli (Holme \& Palmstierna, 1956a-c; Dagley \& Dawes, 1949) and in yeast by Stier \& Stannard (1935-36). Degradation of other macromolecular constituents occurs in bacteria maintained in the absence of added nutrients. For example, Holden (1958) reported that when Lactobacillus arabinosus was incubated in phosphate buffer at $37^{\circ}$, ribonucleic acid (RNA) was degraded, resulting in the release of ultraviolet (u.v.) absorbing substances into the 
medium; a similar phenomenon was investigated in yeast (Higuchi \& Uemura, 1959). Turnover of protein occurs in Escherichia coli maintained at growth temperature in the absence of nutrients (Mandelstam, 1958 $a, b$; Mandelstam \& Halvorson, 1960). We have studied the survival of stationary phase Aerobacter aerogenes organisms suspended in buffer solution and have investigated gross changes in the concentrations of endogenous RNA, protein and carbohydrate.

\section{METHODS}

The strain of Aerobacter aerogenes used was obtained from Professor Sir Cyril Hinshelwood's laboratory.

Media. (a) Defined medium usually contained (g./l.): $\mathrm{NaH}_{2} \mathrm{PO}_{4}, 0 \cdot 6 ;\left(\mathrm{NH}_{4}\right)_{2} \mathrm{HPO}_{4}$, $5.95 ; \mathrm{K}_{2} \mathrm{SO}_{4}, 1.75$; mannitol, 10 ; and salt mixture $(5 \mathrm{ml}$.). Salt mixture was prepared by dissolving $\mathrm{MgO}\left(10 \mathrm{~g}\right.$.), $\mathrm{CaCO}_{3}(1 \mathrm{~g}),. \mathrm{ZnO}\left(0 \cdot 16 \mathrm{~g}\right.$.), $\mathrm{FeCl}_{3} \cdot 6 \mathrm{H}_{2} \mathrm{O}(2 \cdot 7 \mathrm{~g})$. and $\mathrm{MnCl}_{2} \cdot 4 \mathrm{H}_{2} \mathrm{O}(0.4 \mathrm{~g}$.) in water $(200 \mathrm{ml}$.) containing conc. $\mathrm{HCl}(50 \mathrm{ml}$. $)$ and diluting to $1 \mathrm{l}$. with water. The final medium was sterilized by autoclaving $\left(120^{\circ}\right.$, 15 min.). (b) Tryptic meat broth, prepared from bullock's meat, contained $2.5 \mathrm{mg}$. nitrogen $/ \mathrm{ml}$. (c) Tryptone glucose (Wade, 1961). A concentrate was prepared by mixing three solutions $(A, B$, and $C$ ) together. Soln. $A: \mathbf{2 \cdot 8} \mathrm{kg}$. of Tryptone (Oxo Ltd., London) were mixed with 1.05 l. of $2 \mathrm{M}-\mathrm{K}_{2} \mathrm{HPO}_{4}$ and made up to $19 \cdot 6 \mathrm{l}$. with water. The solution was adjusted to $\mathrm{pH} 9.3$ with $\mathrm{NaOH}$, brought to $100^{\circ}$ for $5 \mathrm{~min}$., then filtered (Green's filter-paper no. 904). Citric acid (112 g.) was added, the solution adjusted to $\mathrm{pH} 7 \cdot 6$ with $\mathrm{HCl}$ and the volume re-adjusted with water to 19.6 l. The solution was autoclaved in volumes of $2 \cdot 81$. at $115^{\circ}$ for $30 \mathrm{~min}$. Soln. B: $406 \mathrm{~g}$. $\mathrm{NaCl}, 140 \mathrm{ml}$. $\mathrm{M}$-ferric citrate, $14 \mathrm{ml} . \mathrm{M}^{-\mathrm{CaCl}_{2}}$ and $560 \mathrm{ml} . \mathrm{M}^{\mathrm{M}} \mathrm{MgSO}_{4}$ were made up to $2 \cdot 81$. with water. Volumes of $750 \mathrm{ml}$. were autoclaved at $115^{\circ}$ for $20 \mathrm{~min}$. Soln. $C: 2.8 \mathrm{~kg}$. glucose were made up to $5.6 \mathrm{l}$. with water and the solution autoclaved in volumes of 11 at $115^{\circ}$ for $10 \mathrm{~min}$. The concentrate was prepared by mixing 2.81 . of soln. $A, 750 \mathrm{ml}$. of soln. $B$ and 1 l. of soln. $C$ together, and stored at $2-5^{\circ}$. The concentrate was diluted with sterile water $(5 \mathrm{vol}$.$) , the final medium$ containing $1.8 \%(\mathrm{w} / \mathrm{v})$ glucose.

Cultural conditions and harvesting. Organisms were grown at $37^{\circ}$ in an apparatus (culture volume $\mathbf{0 . 5}$ or 3 l.) essentially as described by Elsworth, Meakin, Pirt \& Capell (1956) and used as a batch culture vessel. The medium in the culture vessel was seeded with a suspension of organisms grown for $8 \mathrm{hr}$. at $37^{\circ}$ in a flask containing the same medium, aerated by rocking on a shaker; the initial concentration in the culture vessel was about $10^{8}$ living bacteria $/ \mathrm{ml}$. medium. Filtered air was passed through the impeller at $1 \mathrm{ml} . / \mathrm{min}$./ml. culture and the $\mathrm{pH}$ value was continuously maintained at $\mathbf{7 \cdot 2}$. Cultures reached the stationary phase in $6 \mathrm{hr}$. or less with media described above. Bacteria were harvested by centrifugation, washed twice with buffer solution and resuspended at about $10^{10}$ bacteria/ml. in the same buffer solution. The solution used for washing and resuspending the organisms contained $\mathrm{NaCl}(0 \cdot 13 \mathrm{M})$ and $\mathrm{KH}_{2} \mathrm{PO}_{4}+\mathrm{K}_{2} \mathrm{HPO}_{4}\left(0.02 \mathrm{M}-\mathrm{PO}_{4}\right)$; final value $\mathrm{pH} 6.5$.

Bacteria counting procedures. Total bacterial counts were made with a Thoma chamber and dark ground illumination (average of three determinations on each sample). Organisms within one-fifth of the ruled area were counted and samples were diluted with buffered saline ( $\mathrm{pH} \mathrm{6.5)}$ so that the number present was 250-500. The 
results obtained when 20 determinations were made on one sample varied between 298 and 368 (mean, 328; standard deviation, \pm 21 ). Counts of viable bacteria were made by spreading $0.2 \mathrm{ml}$. sample (diluted by successive tenfold dilutions with buffered saline to contain 500-1000 viable organisms $/ \mathrm{ml}$.) on the dried surface of each of five nutrient agar plates. Colonies were counted after incubation for $24 \mathrm{hr}$. at $37^{\circ}$. When the dilution and plating procedure was repeated 20 times with one suspension, the number of colonies/ml. counted varied between 689 and 852 (mean, 777; standard deviation, \pm 57 ). A direct determination of the $\%$ viable bacteria in a suspension was made by the slide culture method of Postgate, Crumpton \& Hunter (1961) with tryptic meat broth agar and dark ground illumination. Microcolonies and undivided organisms were counted after incubation for about $3.5 \mathrm{hr}$. at $37^{\circ}$. When the \% viability of one suspension was determined twelve times by this technique, results varied between 93.5 and $96 \cdot 8$ (mean, $95 \cdot 7$; standard deviation, \pm 0.90 ).

Storage of suspensions of Aerobacter aerogenes. Sterility precautions were taken during the preparation, storage and sampling of bacterial suspensions. For storage at $37^{\circ}$ with aeration, a suspension of washed freshly harvested organisms (usually $500 \mathrm{ml}$; ; about $10^{10}$ bacteria $/ \mathrm{ml}$.; dry weight about $2.5 \mathrm{mg} . / \mathrm{ml}$.) at $\mathrm{pH} 6.5$, was transferred to a sterilized gas wash bottle (1 1.; Dreschel pattern) held in a water bath at $37^{\circ}$. Washed filtered air was passed $(0 \cdot 2 \mathrm{l} . / \mathrm{min}$.) into the suspension through a sintered glass disk and the effluent air allowed to escape through a water reflux condenser fitted with a cottonwool filter. During the storage period, the $\mathrm{pH}$ value of the suspension was measured at intervals and, when necessary, adjusted to $\mathrm{pH} 6.5$ by the slow addition of $\mathrm{N}-\mathrm{NaOH}$ or $\mathrm{N}-\mathrm{HCl}$. Samples were removed at intervals for determinations of total and viable counts, \% viability by the slide culture method, dry weights and chemical analyses. Samples for chemical analysis were centrifuged to separate the bacteria and the supernatant liquid was filtered through a Millipore bacteriological filter. The deposit of bacteria was washed with buffered saline by centrifugation and resuspended in water to known volume at a concentration of about $5 \mathrm{mg}$. dry weight/ml.; bacterial suspensions and filtered supernatant fluids were stored in the frozen state when not analysed immediately.

Analytical methods. Nucleic acids were determined in washed freeze-dried bacteria by the method of Schmidt \& Thannhauser (1945); results were expressed in terms of nucleic acid phosphorus. Loss of RNA from Aerobacter aerogenes during storage was followed with the Schneider (1945) method applied to bacteria separated from suspensions by centrifugation; pentose in the hot trichloroacetic acid (TCA) fraction was estimated by the colorimetric method described by Morse \& Carter (1949) or by the Dische \& Borenfreund (1957) method, and converted to RNA by comparison of the colour obtained with that given by a known weight of yeast RNA (P, $8.1 \%$; assumed to be $85 \%$ RNA). Bacterial pentose excluding pyrimidine pentose was determined with the Bial reaction (Morse \& Carter, 1949) applied directly to a suspension; dried ribose (Laboratory Reagent Grade from The British Drug Houses Ltd., Poole) was used as the standard. Hexose interfered in the method and allowance was made for interfering carbohydrate in $A$. aerogenes by determining total carbohydrate in the bacterial suspension with the sulphonated resorcinol method of Devor, Conger \& Gill (1958); dried ANALAR glucose from The British Drug Houses Ltd. was used as the standard. Light absorption was measured at $500 \mathrm{~m} \mu$ 
and, at this wavelength, ribose gave 96-102\% of the colour given by an equal weight of glucose. In the Bial method, light absorption was measured at $660 \mathrm{~m} \mu$ and glucose gave $11-15 \%$ of the reading given by an equal weight of ribose. If $x=$ 'true glucose' $(\mu \mathrm{g} . / \mathrm{ml}$.), $y=$ 'true pentose excluding pyrimidine pentose' ( $\mu \mathrm{g} . / \mathrm{ml}$.), $a=$ total carbohydrate found $(\mu \mathrm{g} . / \mathrm{ml}$.) and $b=$ pentose found $(\mu \mathrm{g} . / \mathrm{ml}$.$) ,$ then $x+0 \cdot 99 y=a$ and $0 \cdot 13 x+y=b$; interference factors for $x$ and $y$ were determined for each batch of analyses. The results obtained for 'true pentose excluding pyrimidine pentose' by solving the equations, were close to values obtained for purine pentose in the hot TCA fraction (Schneider, 1945) and, in many experiments, RNA loss from suspensions was determined by application of the Bial and resorcinol methods. Total phosphorus in freeze-dried bacteria was determined by the method of King (1932) and total nitrogen by a Kjeldahl method after reduction of the sample with hydriodic acid and red phosphorus (Friedrich, 1933) in a Kjeldahl flask. Protein was determined by means of a Biuret method after the bacteria had been dissolved by heating in $\mathrm{N}-\mathrm{NaOH}$ for $5 \mathrm{~min}$. at $\mathbf{1 0 0}^{\circ}$ (Stickland, 1951); dried bovine plasma albumin (N, 15.9\%) from Armour and Co. Ltd., Hampden Park, Eastbourne, was used as standard. Ammonia was determined by nesslerization after distillation of the sample in a Markham still with alkaline phosphate + borate buffer (Tracey, 1952). Keto acids were estimated by the method of Friedmann \& Haugen (1943); individual keto acids were identified according to the paper chromatographic method of El Hawary \& Thompson (1953). Sugars were identified by paper chromatography on Whatman no. 1 paper with ethyl acetate + pyridine + water $(2+1+2, v / v)$ as solvent (Jermyn \& Isherwood, 1949) and aniline phthalate as spray reagent (Partridge, 1949). For the paper chromatographic detection of amino acids, butanol + acetic acid + water $(4+1+5, \mathrm{v} / \mathrm{v})$ was used as solvent and ninhydrin as the spray reagent. Free amino acids were extracted from bacteria by heating suspensions in distilled water $(20 \mathrm{mg}$. dry wt./ml.) for $20 \mathrm{~min}$. The extract was separated by centrifugation and desalted by passage through a column of Amberlite IR-120 ( $\mathrm{H}$ form). The column was washed with water and the amino acids eluted with pyridine water $(10 \%, \mathrm{v} / \mathrm{v})$. The eluate was concentrated to small volume and chromatographed. Free amino acids released into the suspending medium during storage were detected after the suspension was freed from organisms by centrifugation and filtration through a Millipore filter. The filtrate was desalted in an electrolytic desalting apparatus, reduced to a small volume and chromatographed. Ultraviolet absorption was measured in a Unicam quartz spectrophotometer, model S.P. 500, with a $1 \mathrm{~cm}$. light path. The dry weight of a suspension was determined by centrifuging a measured volume, washing the deposit once with saline $(\mathrm{NaCl}, 0.85 \%$, w/v) containing $\mathrm{HCHO}(3 \%, \mathrm{w} / \mathrm{v})$ and once with water, and drying the deposit at $100^{\circ}$ for $16 \mathrm{hr}$.

Isolation of glycogen from Aerobacter aerogenes harvested from tryptone glucose medium. Freeze-dried organisms (1.5 g.) suspended in water $(50 \mathrm{ml}$.) were disintegrated in the presence of ballotini beads (size 12) and capryl alcohol in a Mickle (1948) tissue disintegrator. The homogenate was centrifuged at $6000 \mathrm{~g}$ for $30 \mathrm{~min}$. and the supernatant liquid separated. TCA solution $(25 \%, \mathrm{w} / \mathrm{v})$ was added to the cold supernatant liquid to a concentration of $2.5 \%(\mathrm{w} / \mathrm{v})$ TCA and the precipitate separated by centrifugation. The supernatant liquid was neutralized by addition of solid $\mathrm{NaHCO}_{3}$ and dialysed against running distilled water at $2^{\circ}$ for $24 \mathrm{hr}$. The sac 
contents were concentrated to $16 \mathrm{ml}$. under reduced pressure and treated with 3 volumes of ethanol and 2-3 drops saturated ethanolic potassium acetate solution. After standing for $24 \mathrm{hr}$. at $2^{\circ}$ the precipitate was isolated by centrifugation, washed with ethanol and dried in vacuo. The yield was $140 \mathrm{mg}$. (=9.3\% dry wt. bacteria); carbohydrate content, $85 \%$ (as glucose). Further fractionation with ethanol resulted in a fraction containing $97 \%$ carbohydrate (as glucose) which, after acid hydrolysis and paper chromatography, gave one spot corresponding in position to glucose. The isolated material gave an opalescent solution in water and reacted with iodine solution to give a reddish violet colour.

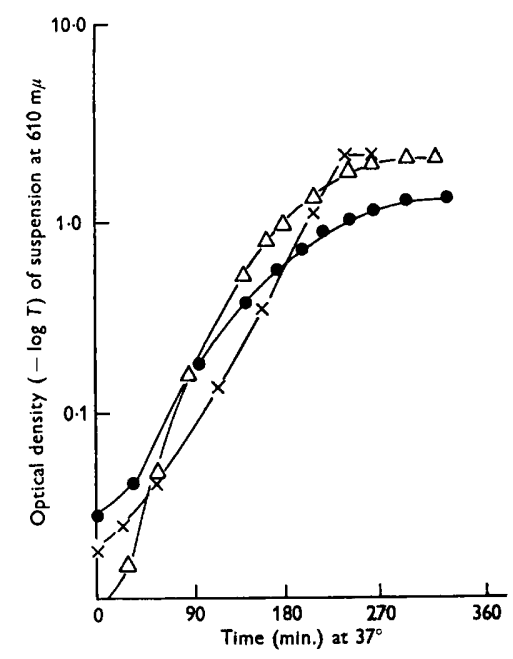

Fig. 1. Growth curves for Aerobacter aerogenes in defined medium ( $\times$ ), tryptic meat broth $(O)$ and tryptone glucose medium $(\Delta)$.

\section{RESULTS}

Growth curves for Aerobacter aerogenes grown in defined medium, tryptic meat broth and tryptone glucose medium in the fermenter are shown in Fig. 1. Growth was determined by turbidity measurements at $610 \mathrm{~m} \mu$ in a Coleman Junior spectrophotometer with the appropriate medium as blank and, when necessary, the sample and blank were diluted with buffered saline $(\mathrm{pH} \mathrm{6 \cdot 5)}$ so that the optical density reading was not greater than $\mathbf{0} \cdot \mathbf{2 5}$. The shape of the growth curve depended on the medium used and with the defined medium the change from the exponential phase into the stationary phase was sharp whereas, with either of the complex media, the turn was more gradual. Bacteria were harvested after growth had ceased for $0 \cdot 5 \mathrm{hr}$. unless otherwise stated. The viability of washed suspensions of bacteria freshly harvested from any of the three media was high (93-99\%) according to the slideculture method of Postgate et al. (1961).

The Postgate et al. method determines only the \% viability of a suspension and not the total number of bacteria present. It was important in the present work, to know whether the total number of organisms in a given suspension changed during storage and, for this reason, total and viable counts were determined. In our hands, 
the coefficients of variation for the results of slide-culture viability determinations, total counts and viable counts were $\pm 0.95, \pm 6 \cdot 4$ and $\pm 7 \cdot 4 \%$ respectively (see Methods). Evidently results for the \% viability of suspensions determined by the slide-culture method were more reliable than those derived from a combination of total and viable counts, provided the generation time of individual organisms did not exceed the incubation period allowed (3.5 hr.). A comparison of the results for $\%$ viability of an aerated suspension of Aerobacter aerogenes during storage at $37^{\circ}$ as determined by the slide-culture technique and from viable and total counts is shown in Table 1 . The values obtained with the Postgate et al. method were usually higher than those derived from the other methods. On the other hand, when the \% viabilities of more aged suspensions were determined, it was frequently found that values by the slide culture method were lower than those derived from total and viable counts. This was probably related to the long lag phase of a proportion of an aged population. The incubation period of slide cultures could not be extended much beyond $3.5 \mathrm{hr}$. otherwise large colonies from single organisms with short generation times overgrew the non-growing bacteria. The shapes of survival curves plotted with data obtained by either the slide-culture technique or by total and viable counts were similar for periods during which biochemical changes occurring within the bacteria were studied.

Table 1. Comparison of the results obtained for the $\%$ viability of an aerated suspension of stationary phase Aerobacter aerogenes during storage at $37^{\circ}$ determined $(a)$ by the method of Postgate et al. (1960); (b) from total and viable counts

Organisms harvested from tryptic meat broth were washed twice with sodium chloride + potassium phosphate solution ( $\mathrm{pH} \mathrm{6.5)}$ and resuspended in the same solution.

\begin{tabular}{|c|c|c|c|c|c|c|c|c|}
\hline Time of storage (hr.) & $\mathbf{0}$ & 16 & 24 & 40 & 48 & 64 & 72 & 88 \\
\hline (1) Total cell count $\times 10^{-10}$ & $1 \cdot 13$ & $1 \cdot 11$ & $\mathbf{1 \cdot 2 7}$ & $1 \cdot 16$ & 一 & - & - & $1 \cdot 17$ \\
\hline (2) Viable cell count $\times 10^{-10}$ & 0.98 & 0.95 & 0.90 & 0.96 & 0.95 & 0.75 & 0.73 & $0 \cdot 60$ \\
\hline $\begin{array}{l}\text { (3) } \% \text { viability }((2) /(1) \times \\
100)\end{array}$ & 87 & $86 \cdot 5$ & 71 & 83 & - & - & - & $\mathbf{5 1}$ \\
\hline $\begin{array}{l}\text { (4) \% viability by the } \\
\text { method of Postgate } \\
\text { et al. }(1961)\end{array}$ & $97 \cdot 5$ & 98 & 96 & 90 & 87 & 78 & 68 & 59 \\
\hline
\end{tabular}

Some of the factors which affected survival of washed bacteria were investigated. In the $\mathrm{pH}$ range 4-9 with Michaelis (1931) constant ionic strength buffers, the optimum value for survival of suspensions (about $10^{10}$ organisms $/ \mathrm{ml}$.) stored at $20-22^{\circ}$ under nitrogen was near $\mathrm{pH} \mathrm{6.5}$; in the range $\mathrm{pH} 5-8$ with orthophosphate buffers $(0.02 \mathrm{M}$ $\mathrm{PO}_{4}$ ) in sodium chloride (0.13 $\mathrm{M}$ ) solutions, a similar $\mathrm{pH}$ optimum was found with suspensions stored under these conditions or at $37^{\circ}$ with aeration. A solution of buffered sodium chloride ( $\mathrm{pH} \mathrm{6.5)} \mathrm{was} \mathrm{used} \mathrm{routinely} \mathrm{for} \mathrm{washing} \mathrm{and} \mathrm{suspending}$ bacteria. This solution appeared to be non-toxic since bacterial suspensions stored at $20-22^{\circ}$ under air or nitrogen survived almost completely for days and in some cases for weeks. It was found that at $37^{\circ}$ with aeration, the initial bacterial concentration affected survival of a population. Initial concentrations of less than $10^{7}$ organisms $/ \mathrm{ml}$. multiplied to $10^{8}-10^{7} / \mathrm{ml}$. within $70 \mathrm{hr}$. This is in agreement with the work of Garvie (1955) who found that Escherichia coli multiplied in buffer solution prepared from specially purified salts dissolved in distilled water. Above a 
concentration of $10^{7}-10^{8}$ bacteria/ml. significant multiplication did not occur and the length of the initial period of almost complete survival decreased as the concentration of organisms was increased to $10^{10} / \mathrm{ml}$. A concentration of about $10^{10}$ organisms $/ \mathrm{ml}$. was used routinely because this avoided maintenance of a significant proportion of the population by contaminating nutrients present in the buffer and also was convenient for subsequent chemical analyses. The shape of survival curves for suspensions of bacteria, particularly those harvested from defined medium, stored at a concentration of about $10^{10} / \mathrm{ml}$. sometimes showed evidence of regrowth; this was probably due to the utilization of material obtained from dying or dead organisms (Harrison, 1960). Regrowth was decreased when bacterial suspensions in cellophan sacs were dialysed against buffered saline. The survival of bacteria depended on the growth phase of the organisms at the time of harvesting. Survival curves for bacteria harvested from defined medium during the late exponential growth phase and at different times in the stationary phase (Fig. 2) showed that extension of the stationary phase under growth conditions favoured survival. The composition of the medium used for growing the bacteria affected their subsequent survival in buffered saline. Organisms harvested from tryptone glucose medium survived best and those harvested from tryptic meat broth usually survived better than bacteria grown in carbon-limiting defined medium. This was true during storage at $37^{\circ}$ with aeration (Fig. 3), or at $20-22^{\circ}$ under nitrogen; under the latter conditions the initial periods of almost complete survival were about 15, 10 and 4. days for organisms harvested from tryptone glucose medium, tryptic meat broth and carbon-limiting defined medium, respectively.

Analyses of bacteria grown in different media. Analyses of well-washed freeze-dried stationary phase bacteria harvested from the three media are shown in Table 2. On a dry-weight basis, bacteria grown in tryptone glucose medium contained 3-4 times as much carbohydrate (as glucose) excluding pentose and about half as much RNA as bacteria grown in the defined medium. Bacteria grown in tryptic meat broth contained a relatively large amount of protein and less RNA than did bacteria from the defined medium. Poly- $\beta$-hydroxybutyric acid (Lemoigne, 1927; Forsyth, Hayward \& Roberts, 1958) was not detected in chloroform extracts of 1 g. amounts of freeze-dried bacteria which had been grown in any of these media. Besides differences in chemical analyses the bacteria varied in average weight according to whether they were grown in defined or complex medium (Table 2). Stationary phase bacteria harvested from defined medium were metabolically more active than bacteria from tryptone glucose medium. For example, $\boldsymbol{Q}_{\mathrm{o}_{2}}(\mu \mathrm{l}$./hr./bacterium) values for washed bacteria during the period when the rate of oxygen uptake was constant, were 5.2 and $2.36 \times 10^{-9}$ for organisms from the defined medium and from the tryptone glucose medium, respectively; in the presence of mannitol $(1 \%$, w/v) $Q_{\mathrm{O}_{2}}$ values of 2.07 and $0 \cdot 64 \times 10^{-7}$, respectively, were obtained.

The high carbohydrate content of bacteria harvested from tryptone glucose medium (Table 2) was due to the presence of glycogen; this was isolated from the organisms (see Methods). Significant amounts of glycogen were not found in homogenates of organisms harvested from carbon-limiting defined medium or from tryptic meat broth. 


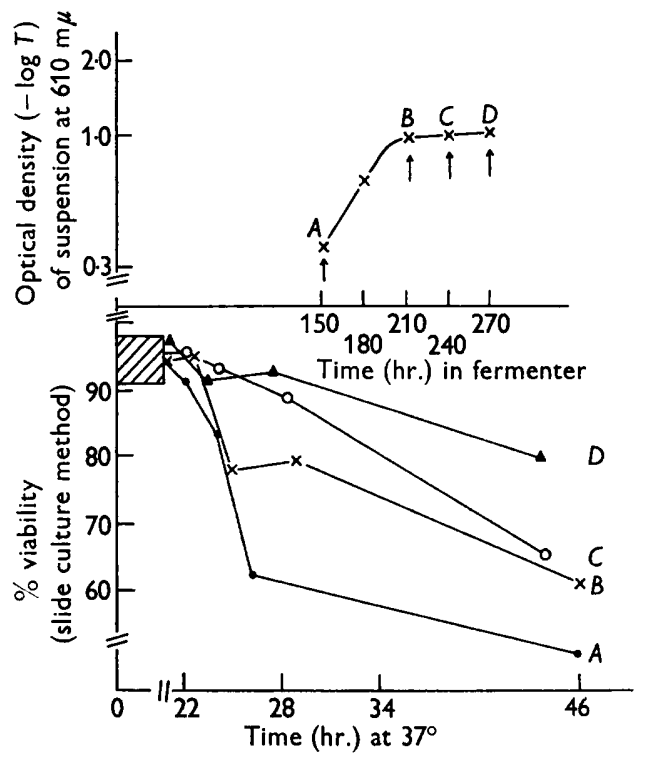

Fig. 2

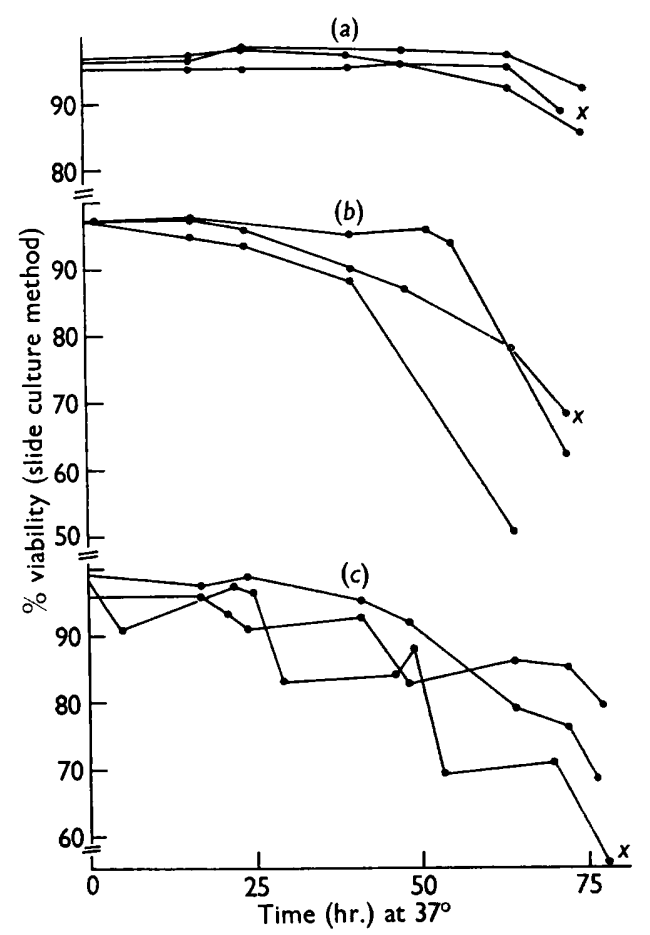

Fig. 3

Fig. 2. Survival of Aerobacter aerogenes harvested from defined medium during the exponential and stationary phases of growth. Arrows on upper curve indicate when samples $(A-D)$ were taken. Lower curves show survival of washed bacteria from samples $A-D$ during storage in buffered saline (pH 6.5) at $37^{\circ}$ with aeration. Viability determined by the method of Postgate et al. (1961). Viability of all four suspensions determined at $0,1,2,3,4,5$ and $20 \mathrm{hr}$. was $91-98 \%$; this is indicated by the hatched area.

Fig. 3. Survival curves for Aerobacter aerogenes harvested $0.5 \mathrm{hr}$. after cultures had reachell stationary phase in: $(a)$ tryptone glucose medium; $(b)$ tryptic meat broth; (c) defined medium. Washed bacteria were stored in buffered saline (pH 6.5) at $37^{\circ}$ with aeration. Curves marked ' $x$ ' and Figs. 4-9 refer to the same experiments (see text).

Table 2. Analysis of washed freeze-dried stationary phase Aerobacter aerogenes harvested from different media

Total

carbohydrate

$\begin{array}{ccccccc} & \text { Total } & \text { Total } & \text { Total excluding Total } & \text { RNA } & \text { DNA } \\ \text { Average } & \mathbf{N} & \mathbf{P} & \text { protein pentose pentose* } & \mathbf{P} & \mathbf{P}\end{array}$

dry wt./

(g./100 g.)

Medium (g. $\left.\times 10^{13}\right)$

Defined

$3 \cdot 47$

Tryptone glucose $\quad \mathbf{2 \cdot 4 2}$

$\begin{array}{lllllll}13.6 & 2.77 & 66 & 5.8 & 5.6 & 1.66 & 0.31\end{array}$

Tryptic meat broth

$\mathbf{2 \cdot 2 5}$

$11 \cdot 6 \quad 1.95$

60

15-20

$\mathbf{3 \cdot 7}$

$0 \cdot 87$

$0 \cdot 38$

$13 \cdot 9 \quad 2 \cdot 14$

$3 \cdot 8$

$4 \cdot 0$

$\mathbf{1} \cdot 09$

$0 \cdot 49$

* Excluding pyrimidine pentose 


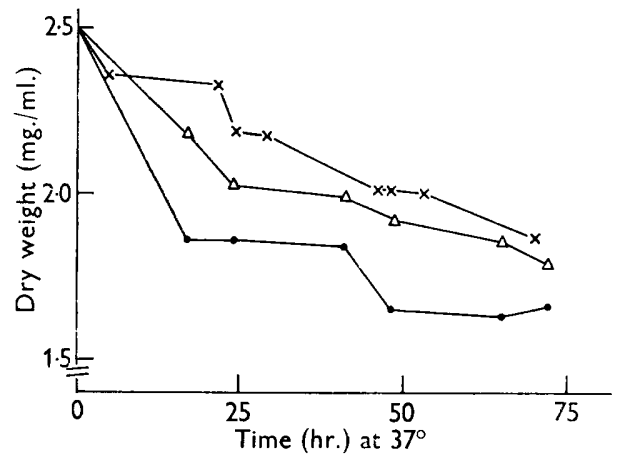

Fig. 4. Loss of dry weight.

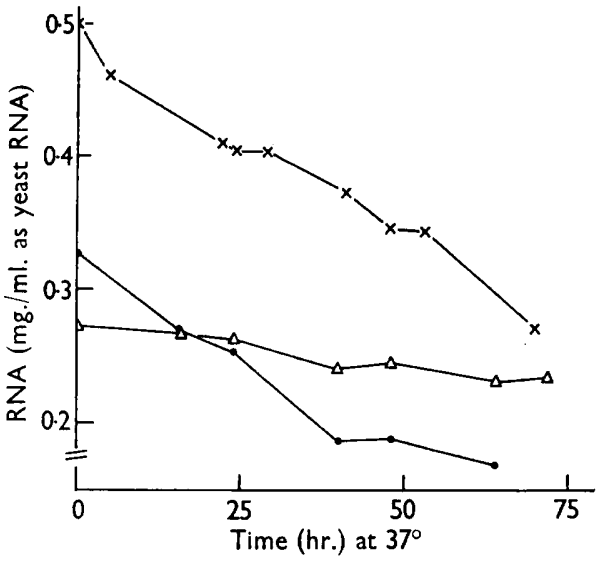

Fig. 6. Loss of RNA (determined by the Schneider, 1945, method).

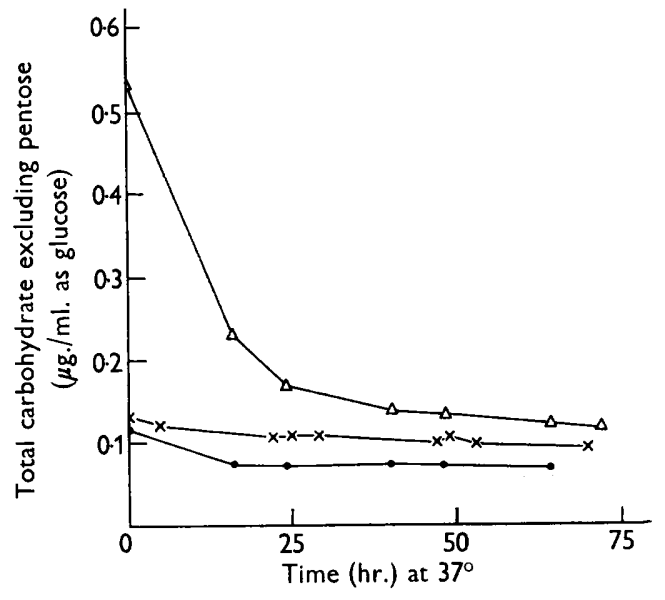

Fig. 5. Loss of glycogen.

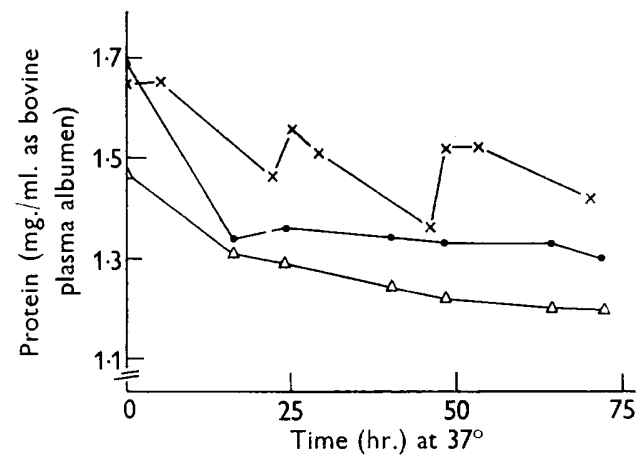

Fig. 7. Loss of protein.

Figs. 4-7. Loss of macromolecular constituents from washed Aerobacter aerogenes during storage in buffered saline (pH 6.5) at $37^{\circ}$ with aeration. Bacteria harvested after $0.5 \mathrm{hr}$. in stationary phase from tryptone glucose medium $(\Delta)$, tryptic meat broth $(\odot)$ and defined medium $(x)$.

\section{Losses of protein, RNA and glycogen from stationary phase bacterial suspensions}

Suspensions of washed bacteria (about $10^{10} / \mathrm{ml}$.) freshly harvested from the three media were incubated at $37^{\circ}$, with aeration, in gas wash bottles. Samples were removed at intervals for determinations of $\mathrm{pH}$ value, total bacterial count, viability and chemical analysis. The data shown (Figs. 4-9) are those for one typical experiment with bacteria harvested from each of the three media; in each case the results were adjusted for a dry weight of $2.5 \mathrm{mg}$. organisms $/ \mathrm{ml}$. at $t=0$. Survival curves referring to the suspensions investigated are shown in Fig. $3 a-c(\times)$. Considering first bacteria harvested from tryptone glucose medium, their initial viability of $95 \%$ was maintained for at least $65 \mathrm{hr}$. (slide-culture method; Fig. 3a, $\times$ ). At 0, 16, 24, 48 and $64 \mathrm{hr}$., the total counts were $1 \cdot 23,1 \cdot 22,1 \cdot 20,1 \cdot 30$ and $1 \cdot 18$ and viable counts 
$0.94,0.98,0.97,0.93$ and $0.96 \times 10^{10}$ organisms $/ \mathrm{ml}$., respectively. Thus the substantial loss of dry weight which occurred in $65 \mathrm{hr}$. (about $25 \%$; Fig. 4) apparently represented a loss from living bacteria. The dry-weight loss was due mainly to losses of glycogen $(0.41 \mathrm{mg} . / \mathrm{ml}$; Fig. 5), RNA $(0.04 \mathrm{mg} . / \mathrm{ml}$.; Fig. 6) and protein $(0.27$ mg./ml.; Fig. 7). Endogenous glycogen appeared to be metabolized by the bacteria because (1) the carbohydrate content of the supernatant fluid from the suspension did not increase significantly during storage; (2) the keto acid content of the organisms increased about fourfold during the first few hours of storage and then decreased to near the original value in $17 \mathrm{hr}$. The keto acid increase was due mainly to the formation of pyruvic acid. During the period when endogenous keto acid concentration increased, the rate of glycogen loss was high (Fig. 5). The suspension of bacteria harvested from tryptic meat broth had an initial viability of $97.5 \%$ and this was maintained for about $40 \mathrm{hr}$. (slide-culture method; Fig. $3 b, \times$ ); the respective total and viable counts for this suspension are shown in Table 1. Again there was a loss of dry weight during storage (about $25 \%$ in $40 \mathrm{hr}$.; Fig. 4) mainly due to losses of RNA (0.14 mg./ml.; Fig. 6), protein $(0.35 \mathrm{mg} . / \mathrm{ml}$.; Fig. 7), and total carbohydrate excluding pentose (0.04 $\mathrm{mg} / \mathrm{ml}$; Fig. 5). Survival curves for bacteria harvested $0.5 \mathrm{hr}$. after growth had stopped in carbon-limiting defined medium were usually less regular than those for organisms from the complex media (Fig. 3c); the initial viability of the suspension discussed here was $96 \%$, and this was more or less maintained for $40 \mathrm{hr}$. (Fig. 3c, x). At 0, 17, 24, 41 and $64 \mathrm{hr}$., total counts were $0.70,0.80,0.70,0.73,0.74$ and viable counts $0.59,0.54,0.68,0.59,0.40 \times 10^{10}$ organisms $/ \mathrm{ml}$., respectively. The loss of dry weight (about $20 \%$, Fig. 4) which occurred in $40 \mathrm{hr}$. was mainly due to losses of RNA (0.15 mg./ml.; Fig. 6), protein $(0.17 \mathrm{mg} . / \mathrm{ml}$; Fig. 7$)$ and total carbohydrate excluding pentose $(0.03 \mathrm{mg} . / \mathrm{ml}$.; Fig. 5). In further experiments, the disappearance of RNA from these bacteria was shown to be most rapid during the first $8 \mathrm{hr}$. (average loss, about $2.0 \% / \mathrm{hr}$.) and the rate decreased during the next $16 \mathrm{hr}$. (average loss, about $1.0 \% / \mathrm{hr}$.).

In parallel with the losses of endogenous constituents there was an excretion into the surrounding medium of material which included ammonia (Fig. 8) u.v.-absorbing substances (Fig. 9) and traces of free amino acids. Bacteria harvested from tryptic meat broth which initially contained the largest amount of protein (68-72\% dry weight), excreted the largest amount of ammonia. Since the total nitrogen of RNA lost from this suspension during storage for $40 \mathrm{hr}$. was equivalent to about $22 \mu \mathrm{g} . / \mathrm{ml}$. and the ammonia-N excreted was $65 \mu \mathrm{g} . / \mathrm{ml}$. it seems probable that some of the ammonia was released as a result of protein degradation. During storage, the concentration of free amino acids in the bacteria or in the surrounding medium did not change sufficiently to explain the protein loss as being due to proteolysis alone. Bacteria harvested from defined medium, from which a considerable amount of RNA was lost (Fig. 6), excreted the largest amount of u.v.-absorbing material; some of this was re-absorbed, presumably by living organisms (Fig. 9). The absorption spectrum of the excreted material showed a broad flat peak extending from 248 to $257 \mathrm{~m} \mu$, similar to that of the material excreted by Lactobacillus arabinosus and investigated by Holden (1958). Analysis of this material by ion-exchange resin chromatography and paper ionophoresis, kindly done by our colleague $\mathbf{M r} \mathbf{H}$. E. Wade, showed that the u.v.-absorbing substances were mainly free bases with a relatively high proportion of hypoxanthine. The presence of hypoxanthine suggested 
that, during storage, adenine nucleotides were degraded, resulting in the release of ammonia and ribose. Since the concentration of pentose, as well as endogenous RNA, decreased, it is evident that ribose was metabolized. Similar losses of RNA, glycogen and protein occurred when bacterial suspensions were held at 20-22 ${ }^{\circ}$ under nitrogen, but at a slower rate.

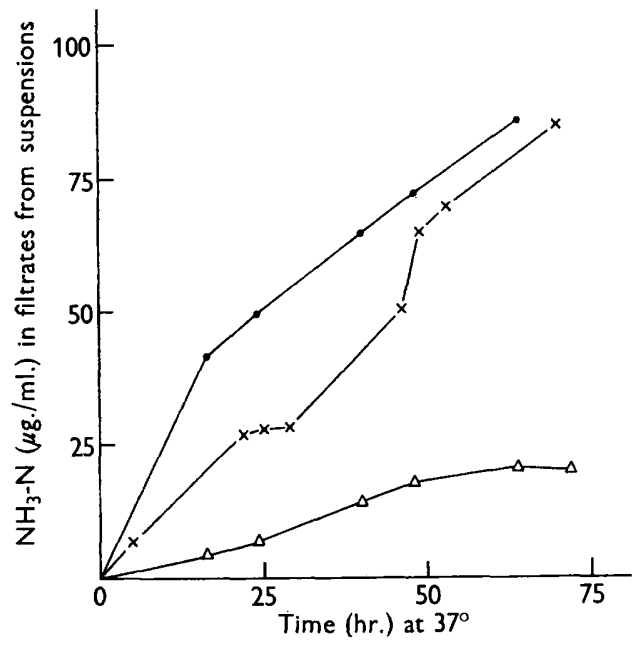

Fig. 8

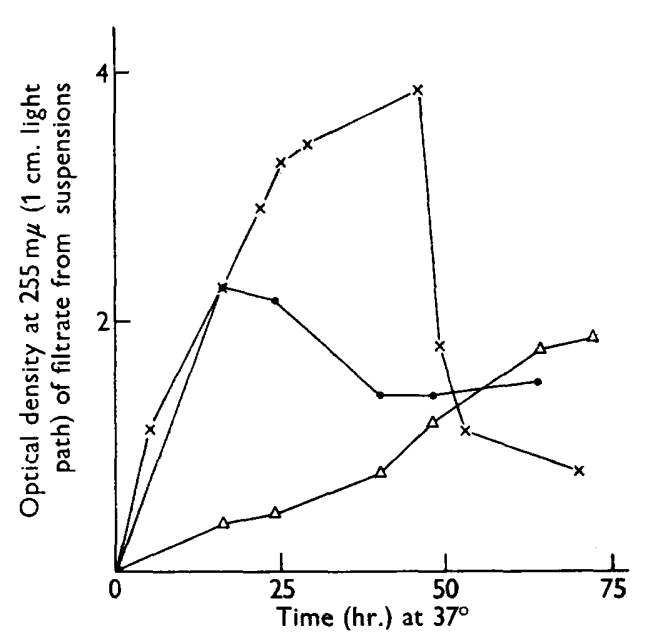

Fig. 9

Fig. 8. Excretion of ammonia by stationary phase Aerobacter aerogenes. Growth media, conditions of storage and symbols as for Fig. 4.

Fig. 9. Excretion of u.v.-absorbing substances by stationary phase Aerobacter aerogenes. Growth media, conditions of storage and symbols as for Fig. 4.

\section{Synthesis of endogenous glycogen by bacteria grown in defined medium}

The defined medium described in Methods contained $1 \%(w / v)$ mannitol and $\mathbf{0 . 1 2} \%(\mathrm{w} / \mathrm{v})$ nitrogen as ammonium salt. Growth was limited by the mannitol and when this had been utilized about $55 \%$ of the nitrogen had been used. When the ammonium salt concentration was decreased by $75 \%$, nitrogen became limiting and, as reported by Holme (1957), glycogen was laid down in the organisms during the stationary phase. The results of a typical experiment are shown in Fig. 10. Bacteria were harvested after $4 \mathrm{hr}$. in the stationary phase from both nitrogen-limiting medium and the normal carbon-limiting medium, and their survival characteristics were compared. The glycogen-containing bacteria survived better than did those without reserves of glycogen.

\section{Effect of added glucose on the survival of bacteria in buffered saline}

Stationary phase bacteria freshly harvested from tryptic meat broth were washed by centrifugation and suspended at a concentration of about $0.6 \times 10^{10}$ viable organisms $/ \mathrm{ml}$. in buffered saline ( $\mathrm{pH} 6 \cdot 5)$. Glucose (to $0 \cdot 45 \%, \mathrm{w} / \mathrm{v}$ ) was added and the suspension incubated at $37^{\circ}$ with aeration. During incubation the $\mathrm{pH}$ value of 
the suspension was controlled by the addition of $\mathrm{NaOH}$. During a $4 \mathrm{hr}$. incubation period, samples were removed for viability determinations and chemical analyses. It was found that about $5 \%$ of the added glucose was turned into cellular glycogen and about $60 \%$ was metabolized (Fig. 11). During the incubation period, $50 \%$ of the bacteria became non-viable; apparently this was due to the presence of glucose, for similar suspensions without added sugar remained completely viable during the experimental period. When similar suspensions containing added glucose were incubated at $37^{\circ}$ under anaerobic conditions (nitrogen) the Pasteur effect was evident, i.e. the substrate was fermented much more rapidly. No cellular glycogen was formed under these conditions. Again about 50\% of the population died during a $4 \mathrm{hr}$. incubation period.

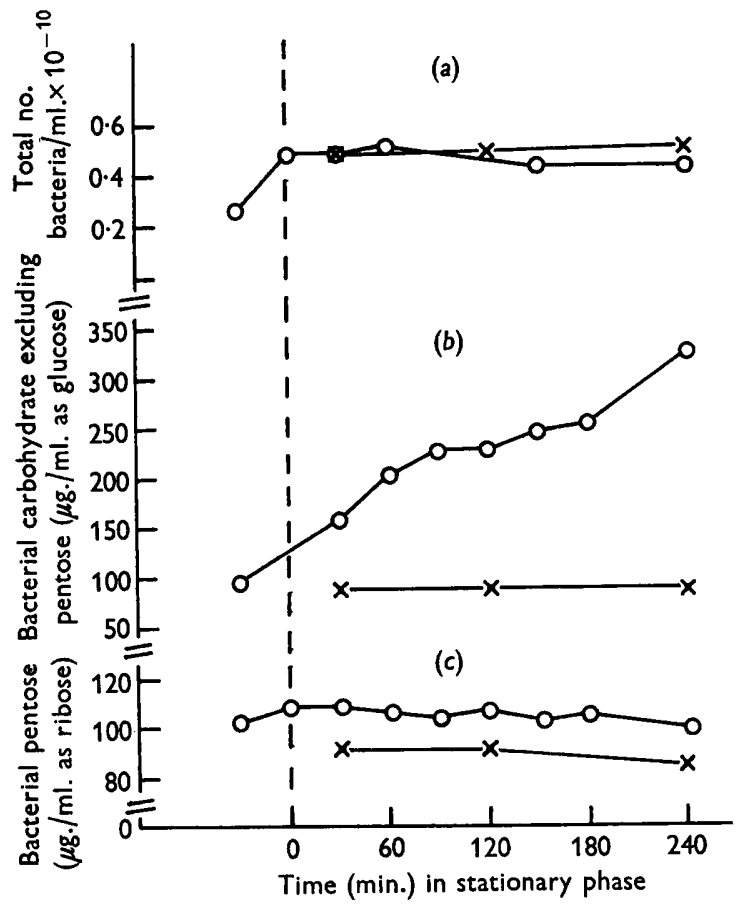

Fig. 10. Synthesis of endogenous glycogen by Aerobacter aerogenes grown in defined medium. Bacteria grown in nitrogen-limited medium $(O) ;(a)$ total count, $(b)$ total carbohydrate excluding pentose in washed cells, $(c)$ total pentose in washed organisms. Some results for bacteria grown in carbon-limited defined medium are shown for comparison $(x)$.

\section{DISCUSSION}

In the present work, populations of stationary phase organisms of Aerobacter aerogenes were grown in a culture vessel under controlled conditions and, in a given medium, their survival characteristics, mean mass and amounts of protein, ribonucleic acid and carbohydrate did not vary greatly from batch to batch. Suspensions of bacteria grown in this way had high initial viabilities which were maintained for periods of hours or days, according to the medium used for growth and the conditions of storage. During this period, degradative changes occurred within the bacteria resulting in the loss of up to $\mathbf{2 5} \%$ of dry weight. Products made available 
by these degradative processes were metabolized by the living organisms and it appeared that their viability was maintained as a result of this. Once a proportion of a bacterial population dies, a comparatively large amount of nutrient material from the corpses may eventually become available to the survivors, thus allowing some of them to grow and divide. When division occurs the population is no longer the original one; in any case chemical changes found to occur after this are difficult

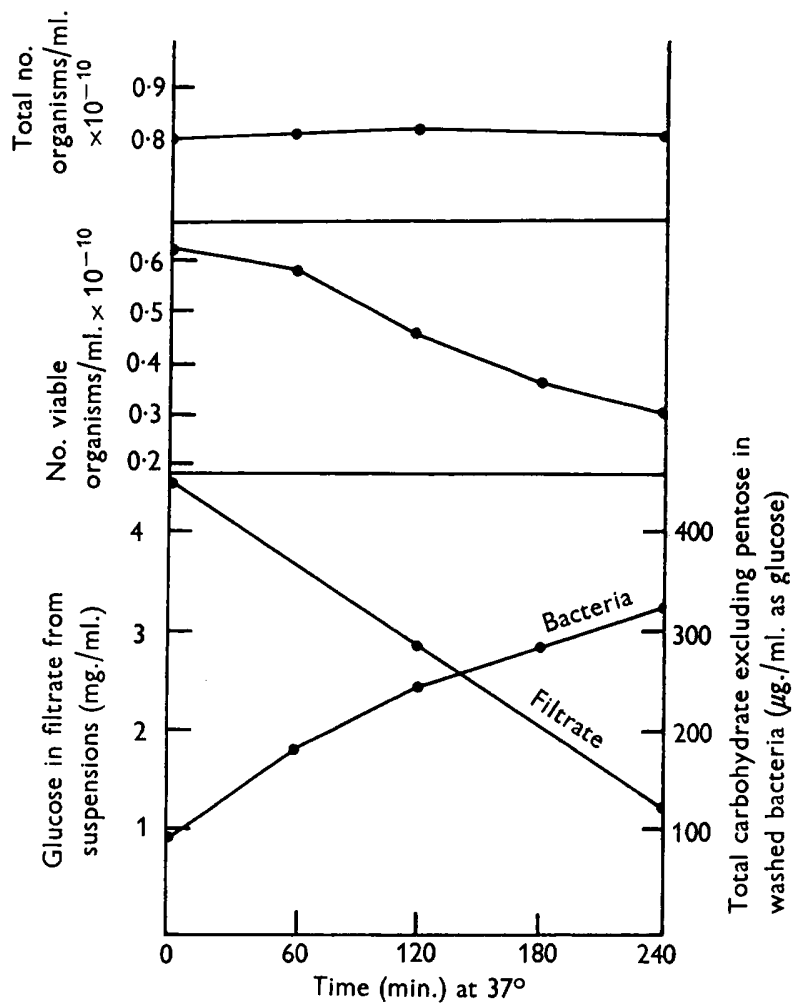

Fig. 11. The effect of exogenous glucose on the survival of Aerobacter aerogenes suspensions stored at $37^{\circ}$ with aeration. Bacteria harvested from tryptic meat broth were washed and resuspended in buffered saline $(\mathrm{pH} \mathrm{6.5})$. Glucose $(4.5 \mathrm{mg} . / \mathrm{ml}$.) was added at zero time.

to interpret since they are occurring in viable and/or dead bacteria. The phenomenon of re-growth in suspensions of $A$. aerogenes held at growth temperature in the absence of nutrients was studied by Harrison (1960). It may be prevented to some extent by dialysing suspensions in cellophan sacs; with such suspensions the survival curve usually showed an initial period of almost complete survival followed by a period of nearly exponential death. This appears to substantiate the hypothesis that bacteria may survive in an unfavourable environment at the expense of endogenous constituents to the stage when further utilization affects cell integrity.

Results of previous studies concerned with the role of glycogen in bacteria and yeasts suggest that in these organisms the substance does not always fulfil the criteria of an energy reserve as it does in animals (Holme, 1957). For example, 
Stier \& Stannard (1935-36) showed that the glycogen of yeast cells decreased slowly when they were suspended in a carbon-free medium, but it was not fermented. Holme (1957) reported that utilization of internal glycogen by Escherichia coli occurred during rapid growth in a complete medium. In bacteria starved of an organic carbon source but supplied with nitrogen, no increase in nitrogen-containing compounds occurred in spite of the fact that 6-8\% of the dry weight of the organisms was glycogen. The fact that bacteria lose internal glycogen during growth and division does not necessarily affect the hypothesis that glycogen serves as a reserve material for stationary phase organisms in an unfavourable environment. Also the fact that bacteria containing 6-8\% glycogen, when put into nitrogen-containing medium, did not synthesize nitrogen-containing compounds is perhaps not so important as whether or not the organisms survived. On this aspect no data are given by Holme and his colleagues. Holme \& Palmstierna (1956d) reported other experiments in which the utilization of glycogen-carbon for synthetic purposes was shown and, as pointed out by Wilkinson (1959), in these experiments internal glycogen did fulfil the criteria of an energy-reserve substance. The results of our survival studies showed that stationary phase organisms containing glycogen survived well in an unfavourable environment. It was found that when cell-free extracts of mechanically disrupted Aerobacter aerogenes were incubated at $37^{\circ}$ with purified glycogen (see Methods) and buffer ( $\mathrm{pH} \mathrm{7 \cdot 2),} \mathrm{glucose} \mathrm{was} \mathrm{released.} \mathrm{No} \mathrm{free}$ glucose was detected in control tubes containing glycogen without extract or extract without glycogen, incubated in parallel. Thus $A$. aerogenes had the mechanism for degrading the polysaccharide and the energy derived from glucose metabolism may have contributed towards the better survival characteristics of glycogen-containing bacteria. However, when glucose was added to an aerated suspension of organisms in buffered saline at $37^{\circ}$, endogenous glycogen equivalent to about $5 \%$ of the added sugar was formed in $4 \mathrm{hr}$. and most of the remaining glucose was metabolized. During the incubation period about $50 \%$ of the population lost their viability. It is possible that the metabolism of a relatively large amount of glucose in the absence of a nitrogen source caused the degradation or denaturation of internal substances, such as enzymes, which could not be replaced.

It has been shown that the ribonucleic acid of stationary phase Lactobacillus arabinosus stored in buffer at $37^{\circ}$ is degraded (Holden, 1958); in our experiments with Aerobacter aerogenes a similar process occurred which had no immediate effect on viability. Stephenson \& Trim (1938) showed that washed suspensions of Escherichia coli were able to degrade adenine nucleotides and that the products of the reaction were hypoxanthine, inorganic phosphate, ammonia and ribose; ribose did not accumulate but was fermented. Eggleston \& Krebs (1959) extended this work. We found that when cell-free extracts of $A$. aerogenes were incubated with

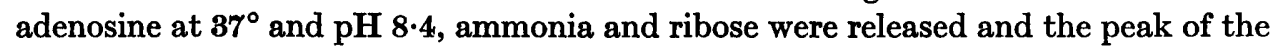
reaction mixture absorption spectrum minus the absorption spectrum of the extract shifted from 257 to $247 \mathrm{~m} \mu$, the latter being the wavelength of maximum absorption of hypoxanthine. Similarly cytidine was converted to uracil on incubation with cell extract. The excretion of free bases, including hypoxanthine, by suspensions of viable $\boldsymbol{A}$. aerogenes suggests that the degradation of ribonucleic acid may provide the bacteria with readily metabolizable sources of carbon (ribose) and nitrogen (ammonia). 
Data about protein turnover in Escherichia coli maintained at growth temperature in the absence of nutrients are available from the reports of Mandelstam $(1958 b)$ and Mandelstam \& Halvorson (1960). The rate of protein-degradation was equal to the rate of protein synthesis at about $5 \% / \mathrm{hr}$. It was suggested that the pool of amino acids made available by this process was used for the production of inducible enzymes to cope with changed chemical environments (Mandelstam, 1956; Pollock, 1958). The data were obtained for suspensions incubated for up to $4 \mathrm{hr}$. The results of the present work show that in an unfavourable environment for longer periods, degradation of protein in Aerobacter aerogenes was not in equilibrium with synthesis and apparently went beyond the amino acid stage, resulting in the release of ammonia. This loss of protein did not immediately affect viability, and in some cases up to $\mathbf{2 5} \%$ of the total cell protein was lost before significant deaths occurred in the population. It is evident that the concentrations of major constituents such as protein, ribonucleic acid and glycogen in bacteria vary according to the medium used for their growth and that these substances may be present in excess of the amounts needed for immediate use. It is difficult to prove unequivocally that utilization of these substances allows cells to survive, but the shape of the survival curve obtained in the present work, showing an initial lag period before the population started to die, could be explained on this basis.

We are indebted to Dr D. Herbert for much useful advice and discussion.

\section{REFERENCES}

Dagley, S. \& Dawes, E. A. (1949). Factors influencing the polysaccharide content of Escherichia coli. Biochem. J. 45, 331.

Devor, A. W., Conger, C. \& GiLl, I. (1958). Use of resorcinol for identification and determination of monosaccharide groups. A report on a Gaucher spleen cerebroside. Arch. Biochim. Biophys. 73, 20.

Dische, Z. \& Borenfreund, E. (1957). A new colour reaction for the determination of aldopentose in the presence of other saccharides. Biochim. Biophys. Acta, 23, 639.

Eggleston, L. V. \& Krebs, H. A. (1959). Permeability of Escherichia coli to ribose and ribose nucleotides. Biochem. J. 73, 264.

Er Hawary, M. F. S. \& Thompson, R. H. S. (1953). Separation and estimation of blood keto acids by paper chromatography. Biochem. J. 53, 340.

Elsworth, R., Meakin, L. R. P., Pirt, S. J. \& Capell, G. H. (1956). A two-litre scale continuous culture apparatus for microorganisms. J. appl. Bact. 19, 264.

Forsyth, W. G. C., Hayward, A. C. \& Roberts, J. B. (1958). Occurrence of poly- $\beta$ hydroxybutyric acid in aerobic gram negative bacteria. Nature, Lond. 182, 800.

Friedmand, T. E. \& Haugen, G. E. (1943). Pyruvic acid. II. The determination of keto acids in blood and urine. J. biol. Chem. 147, 415.

Friedrich, A. (1933). In Quantitative Organic Microanalysis (Pregl), 4th edition (1945), p. 78. Ed. J. Grant. London: J. and A. Churchill Ltd.

GARviE, E. I. (1955). The growth of Escherichia coli in buffer substrate and distilled water. J. Bact. 69, 393.

Harrison, A. P. (1960). The response of Bacterium lactis aerogenes when held at growth temperature in the absence of nutriment; an analysis of survival curves. Proc. Roy. Soc. B, 152, 418.

Higuchi, M. \& Uemura, T. (1959). Release of nucleotides from yeast cells. Nature, Lond. 184, 1381.

Holden, J. T. (1958). Degradation of intracellular nucleic acid and leakage of fragments by Lactobacillus arabinosus. Biochim. Biophys. Acta, 29, 667. 
Horme, T. (1957). Bacterial Synthesis During Limited Growth. The Formation of Glycogen and of Nitrogenous Compounds in Escherichia coli $B$ as Infuenced by Nutritional Deficiencies. Uppsala: Almqvist and Wiksells Boktryckeri Ab.

Holme, T. \& Palmstierna, H. $(1956 a, b)$. Changes in glycogen and nitrogen-containing compounds in Escherichia coli $B$ during growth in deficient media. I. Nitrogen and carbon starvation. II. Phosphorus and sulphur starvation. Acta chem. scand. 10, 578, 1553.

Holme, T. \& Palmstierna, H. (1956c). On the synthesis and breakdown of a glycogenlike polysaccharide in Escherichia coli $B$. Acta chem. scand. 10, 155.

Holme, T. \& Palmstierna, H. (1956 d). On the glycogen in Escherichia coli $B$; its synthesis and breakdown and its specific labelling with ${ }^{14} \mathrm{C}$. Acta chem. scand. 10, 1557.

JERMYN, M. A. \& Isherwood, F. A. (1949). Improved separation of sugars on the paper partition chromatogram. Biochem. J. 44, 402.

KInG, E. J. (1932). The colorimetric determination of phosphorus. Biochem. J. $26,292$.

Lemoigne, M. (1927). Microbial autolysis and the autolytic origin of $\beta$-hydroxybutyric acid. Ann. Inst. Pasteur, 41, 148.

MandelstaM, J. (1956). Theories of enzyme adaption in microorganisms. Intern. Rev. Cytol. 5, 51.

MandelstaM, J. (1958 $a$ ). The free amino acids in growing and non-growing populations of Escherichia coli. Biochem. J. 69, 103.

Mandelstam, J. (1958b). Turnover of protein in growing and non-growing populations of Escherichia coli. Biochem. J. 69, 110.

Mandelstam, J. \& Halvonson, H. (1960). Turnover of protein and nucleic acid in soluble and ribosome fractions of non-growing Escherichia coli. Biochem. Biophys. Acta, 40, 43.

Michaelis, L. (1931). The acetate-barbital buffer. Biochem. Z. 234, 139.

MrCkLe, H. (1948). Tissue disintegrator. J. R. micr. Soc. 68, 10.

Morse, M. L. \& CARTER, C. E. (1949). The synthesis of nucleic acids in cultures of Escherichia coli. strains $B$ and $B / R$. J. Bact. 58, 317.

Partridge, S. M. (1949). Aniline hydrogen phthalate as a spraying reagent for chromatography of sugars. Nature, Lond. 164, 443.

Pollock, M. R. (1958). In Enzymes, 1, 619. New York: Academic Press Inc.

Postgate, J. R., Crumpton, J. E. \& Hunter, J. R. (1961). The measurement of bacterial viabilities by slide culture. J. gen. Microbiol. $24,15$.

Schmidt, G. \& Thannhauser, S. J. (1945). A method for the determination of desoxyribonucleic acid, ribonucleic acid and phosphoproteins in animal tissues. J. biol. Chem. $161,83$.

Schneider, W. C. (1945). Phosphorus compounds in animal tissues. I. Extraction and estimation of desoxypentose nucleic acid and of pentose nucleic acid. J. biol. Chem. 161, 293.

Stephenson, M. \& Trim, A. R. (1938). The metabolism of adenine compounds by Bact. coli. Biochem. J. 32, 1740.

STICKLAND, L. H. (1951). The determination of small quantities of bacteria by means of the Biuret reaction. J. gen. Microbiol. 5, 698.

Stier, T. G. B. \& Stannard, J. N. (1935-36). A kinetic analysis of the endogenous respiration of baker's yeast. The metabolic systems involved in dissemination of carbohydrate reserves in baker's yeasts. J. gen. Physiol. 19, 461, 479.

Tracey, M. V. (1952). The determination of glucosamine by alkaline decomposition. Biochem. J. 52, 265.

WADE, H. E. (1961). The autodegradation of ribonucleoprotein from Escherichia coli. Biochem. J. (in the Press).

Wilkinson, J. F. (1959). The problem of energy-storage compounds in bacteria. Expt. Cell Res. (Suppl.), 7, 111. 